\title{
(НОВАТА) КОМПАРАТИВНА МИТОЛОГИЈА: МОЖНОСТИ И ГРАНИЦИ
}

\author{
Маја Бојаџиевска \\ Универзитет „Св. Кирил и Методиј“, Скопје \\ maja.bojadjievska@flf.ukim.edu.mk
}

Компаративната митологија претставува систематско проучување на митови и митски теми кои постојат во различни култури и таа служи за различни академски цели. Почнувајќи од 19 век, научниците ги проучувале релациите помеѓу различните митови за да го откријат развојот на религиите и културите. Постојат теоретичари кои ги подвлекуваат лингвистичките релации помеѓу митовите, теоретичари кои ги осветлуваат сличните психолошки сили зад митските приказни или научници кои посегаат по структуралистичкиот пристап во напорот да ги пронајдат структурите во основата на различните митови. Филогенетската линија на проучување, општо земено, претпоставува дека митовите, слично како гените, се развиваат во наследна линија со модифицирање, а впечатливите паралели помеѓу биолошката и митолошката еволуција ја овозможуваат употребата на компјутерска статистика со која се извлекуваат заклучоци во правец на еволуциската поврзаност и создавање на филогенетски стебла. Еден од најинтересните нови пристапи кон проучување на митот е оној на М. Вицел кој ги објаснува интеркултурните сличности преку човечките универзалии, независната инвенција и дифузијата.

Клучни зборови: мит, компаративна митологија, митски структури, психолошки, лингвистички, антрополошки пристапи 


\title{
NEW COMPARATIVE MYTHOLOGY: POSSIBILITIES AND LIMITATIONS
}

\author{
Maja Bojadzievska \\ Ss Cyril and Methodius University, Skopje \\ maja.bojadjievska@flf.ukim.edu.mk
}

Comparative mythology is defined as systematic comparison of myths and mythic themes drawn from a wide variety of cultures and it served a variety of academic purposes. Starting from $19^{\text {th }}$ century, scholars have examined the relationships between different myths to trace the development of religions and cultures. There were theorists who underline the linguistic relationships between myths, theorists who seek to reveal similar psychological forces behind the mythic stories or scientists who adopt the structuralist approach, looking for underlying structures shared by different myths. The phylogenetic line of study generally speculates that like genes, myths evolve by a process of descent with modification and the striking parallels between biological and mythological evolution allows the use of computational statistics to infer evolutionary relatedness and to build the most likely phylogenetic trees. One of the most interesting new approaches to myth has been proposed by Michael Witzel who explains the cross-cultural similarities of myth in at least three ways other than common origin: human universals, independent invention and diffusion.

Key words: myth, comparative mythology, mythic structures, approaches (linguistic, psychological, anthropological) 
Систематичното проучување на митовите, уште од своите почетоци во втората половина на 19 век, во извесна мера својата основа ја има во историскиот интерес за митот, забележлив и во ренесансата и во периодот на класицизмот во Европа. Тој интерес е веројатно првпат оформен во, како што се смета, првата сериозна филозофија на митот, забележлива во делото Нова наука (Scienza Nuova, 1725) на Џамбатиста Вико. Имено, во своето капитално дело, Вико ја формулира претставата за историјата на цивилизацијата како цикличен процес, во рамките на кој божествената, јуначката и човечката епоха ги рефлектираат детството, младоста и зрелоста на општеството и општиот разум. „Така, нашата Наука“, вели Вико во уводот на своето дело, „воедно станува историја на идеите, обичаите, делата на човештвото. Од овие три, ние ке ги извлечеме принципите на историјата на човековата природа, за кои ќе покажеме дека се принципи на универзалната историја (...) кои досега недостасуваа“ (За поетската мудрост, §368). Зборувајќи за уметноста и поезијата, Вико е веројатно првиот кој поетската мудрост, или, како што ја нарекува, првата мудрост на паганството на конзистентен начин ја доведува во врска со чувствената и фантастична метафизика на првите луѓе, а развојот на поетскиот јазик го доведува во врска со митот.

Втората значајна референца во доменот на филозофското промислување на митот треба да се бара повеќе од стотина години подоцна во делото на германскиот филозоф Шелинг. Шелинг во својата книга Филозофија на мийолог̄ијайа (Philosophie der Mythologie, 1842), спротив-ставувајќи се на евхемеристичкиот ${ }^{1}$ и алегорискиот пристап на митот, се застапува за тезата дека митовите имаат историски развој кој се движи на линијата од првите претстави за природата па се́ до антропоморфната концепција за боговите. Шелинг особено ја нагласува светотворната и естетска димензија на митот сметајќи дека тој е првата материја, но и првата потенција од која произлегува, подоцна, не само книжевноста туку и целата уметност. Митолошките претстави не се создадени со намера нешто да се тврди или да се проучува, вели Шелинг, туку да се задоволи некаков - пред сѐ непоимен - поетски творечки нагон, па затоа, во митологијата има вистина, но не вистина која е со намера во неа положена. Главното прашање во поглед на митологијата, за Шелинг, е прашањето на значењето, а значењето на митологијата може да биде само значење на процесот низ кој таа настанува.

${ }^{1}$ Според Евхемер (4 век пр. н. е), кој ја востановува идејата дека фигурите на боговите во пантеонот, всушност, претставуваат сеќавања на некогашни маркантни историски личности кои вистински постоеле. 
Митологијата, понатаму тврди Шелинг, настанала не вештачки, туку природно, со нужност во која не се разликуваат содржината и формата.

Втемелувањето на компаративната митологија како системско проучување на митологијата, всушност, треба временски да се ситуира малку подоцна во однос на размислувањата на германскиот филозоф. Тоа се случува кон половината на 19 век преку истражувањата на Макс Милер, германски класичен филолог и ориенталист. Од Берлин, каде што студирал заедно со Шелинг и за него ги преведувал индиските Уйанищаgи (и потоа Париз каде што ги продолжува студиите по санскрит) во 1848 год. Макс Милер се преселува во Оксфорд. Тој станува првиот оксфордски професор по компаративна (индоевропска) филологија, а преку своите обемни преведувачки зафати и истражувања на светите книги на истокот (Begu,

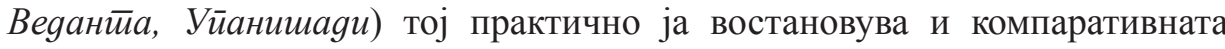
историја на религиите и компаративна митологија. Постулатите на Милер се важни за компаративната митологија. За него, најпрвин, антропоморфните митови се продукти на скршнувањата на јазикот коишто почнуваат од еден загубен оригинал (urtext). Оттука, неговата лингвистичка концепција за настанувањето на првобитните приказни го објаснува митот како семантичко поместување на првобитната смисла во правец на нејзините конкретни обележја. Милер ги реконструира митовите од древната индиска митологија врз основа на проучувањето на Ведите, преку етимолошки споредби кои се движат во рамката на индоевропските јазици, така што самите богови ги замислува како соларни симболи, односно како дескрипција на природни феномени.

\section{1 На трагата на антропологијата}

Потребно е да се нагласи дека, освен оваа филогенетска низа на истражувања, за компаративната митологија од исклучителна важност е развојот на англиската антрополошка школа, особено творештвото на Едвард Тајлор. Тајлор е британски антрополог кој концепциски го обединува поимот култура и начелно, во своето дело Примитиввна кулимура (Primitive culture, 1871) се занимава најпрвин со социјалниот развој, лингвистиката и, секако, митот. Тој е првиот којшто структурно почнува да ја развива науката за културата како посебна дисциплина и во тие рамки ја исцртува својата еволуционистичка теорија на религиите. Вториот том

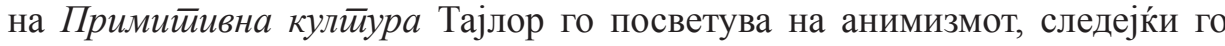
развојот на религиските верувања од анимизмот до монотеизмот преку политеистичките религиски структури. Се разбира, важно е што Тајлор повикува на проучување на митовите во рамките на примитивните религии, 
класифицирајќи ги божествените фигури според централните концепции на нивното значење и функции. За него митовите се инспирирани од сонот или од трансот, но тој ги разгледува во широка етнографска перспектива, во рамките на комплексното единство кое ги вклучува обичаите, законите, знаењето, верувањето и сите други способности со кои се здобива човекот како член на заедницата.

Во контекстот на антрополошките проучувања еден од најбитните опуси за проучувањето на митот е делото на Џејмс Џорџ Фрејзер, Злайнайа Гранка (The Golden Bough, 1911-1915). Фрејзер, кому му забележувале дека е еден вид салонски антрополог, во својата прочуена книга прави, како што се смета, грандиозно патување околу светот на митологиите, свртувајќи ја компаративната митологија во нова орбита. Начелно, ако компаративната митологија претставува споредбена анализа на митовите од различни култури, нејзината втора и најважна димензија - да идентификува заеднички теми и одлики во тој огромен диверзитет и да бара плаузибилно објаснување за таквите феномени - лесно се забележува во заводливата книга на Фрејзер. Имено, Фрејзер силно влијае на науката за митот во тројна перспектива. Најпрвин, тој му се спротивставува на Тајлор и на неговата теорија на анимизмот со првото теориско концептуализирање на магијата. Додека Тајлор го гледа настанокот на митологијата и на религијата во првобитниот анимизам (како верување во душата) што, како што е покажано, е прилично ограничено сфаќање првенствено заради праволинискиот еволуционизам на оваа школа, Фрејзер, во таа смисла, зборува за магијата која според него одговарала на првите степени на човековата свест и мислење. Оттука, Фрејзер ги објаснува ритуалите на жртвување, тотемизмот и календарските култови со помош на магијата, согледувајќи ја како исклучително дифузна категорија на свеста, но и како разнообразна практика. Фрејзер ја прави првата теориска скица на магијата и го истакнува нејзиното значење за првите институции на човештвото (брак, сродство, сопственост, власт) и воопшто, за зацврстувањето и одржувањето на општествениот поредок. Понатаму, Фрејзер го објаснува митот на тој начин што во него гледа отпечаток на ритуалот, еден вид вербална илустрација на ритуалната практика. Третата перспектива, конечно, се однесува на Фрејзеровото согледување на една значајна експликативна матрица, ритуалемата за свештениот крал којшто периодично е убиван и заменуван, под чиј знак тој ги става обредите на смртта и повторното раѓањ - обреди кои, како што забележува британскиот антрополог, можат да се најдат во различни општествени заедници на пет континенти.

Во групата антрополошки истражувања кои се од особена важност за компаративната митологија во првите декади на дваесеттиот век треба да се спомне и функционалистот Бронислав Малиновски, кој спроведува 
социолошко читање на митовите. Тој е полски етнограф кој се здобива со докторат по антропологија во Лондон. Претежно истражувал на Тробријандските Острови во Меланезија и од неговата обемна теренска

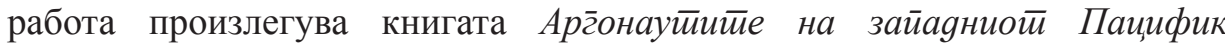
(Argonauts of the Western Pacific) од 1922 година. Според Малиновски, митските приказни имаат нормативна функција и служат за да го оправдаат постоењето на правилата на моралот, општествените рангови и религиските обреди соодветни на секоја култура, така што нивната содржина не може да има универзално потекло. Во врска со прашањето на универзализмот, Малиновски како претставник на социјалната антропологија особено ги предизвикува Фројдовиот концепт за Едиповиот комплекс, тврдејќи дека дури и специфичните психолошки комплекси не можат да бидат универзални.

\section{2 На трагата на психологијата}

Во почетокот на дваесеттиот век, правецот на развој на компаративната митологија е, секако, под влијание на неколку големи авторски имиња од кои треба прв да се спомне Лисјен Леви-Брил, еден од најеминентните претставници на француската социолошка школа (покрај Емил Диркем,

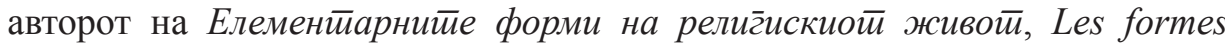
élémentaires de la vie religieuse, 1937). Во 1922 година Леви-Брил го објавува

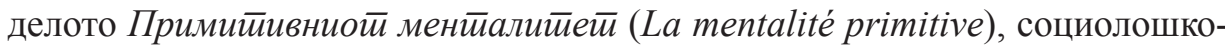
психолошка расправа во која се проучува предлогичкиот степен на свеста кој им претходи на логичките, рационални облици на човековата свест. Леви-Брил ја квалификува примитивната митологија како предрелигиозна, врз основа на испитување на духовниот свет на „примитивните луѓе“ кои, секако, ги наоѓа надвор од Европа. Тој заклучува дека примитивниот менталитет е битно мистичен, дека „тој живее во свет во којшто безбројните и насекаде присутни тајни сили или постојано дејствуваат или се подготвени да дејствуваат“ (Levy-Bruhl 1922: 358). Предрелигиозната примитивна митоло-гија не го разликува природното од натприродното, материјалното од спиритуалното, објектот од субјектот така што старите митски приказни опишуваат натприроден свет, спротивставен на модерната наука.

Леви-Брил е, секако, на трагата на колективната психологија, чии достигнувања, формулирани низ истражувањата на неколку значајни автори, придонесуваат за диверзитетот на методи во споредувањето на митовите. Општо познато е дека Зигмунд Фројд, таткото на психоанализата, во своите истражувања го промовира митот за Едип до нивото на концепт кој ги 
опфаќа конфигурациите на желбата и омразата во кругот на семејството. Во книгата Tомемем и йабу (Totem und Tabu, 1913) виенскиот психоаналитичар се обидува да го детектира присуството на темата на засновувачкото таткоубиство во некои австралиски митови и на тој начин го инаугурира психоаналитичкото читање на митовите, кое е засновано на неговата теза за постоење на универзални нагони кои имаат сексуално потекло. Некои фројдовски ориентирани мислители ги проучувале митските приказни кои покажувале сличности со приказната за Едип во различни, оддалечени култури. И покрај редуктивноста на овие теориски концепти, тие не се без значење за проучувањата на компаративната митологија, слично како и истражувањата на Јунг и на неговите следбеници кои успеале да идентификуваат слики, теми и обрасци коишто се појавуваат во митовите на многу различни култури. Во Јунговата теорија за архетиповите на колективното несвесно се нагласува дека тој голем басен на слики е богат со форми на мислење (праслики) кои се предегзистентни за индивидуата и ги препокриваат инстинктивните поведенија, а најчесто ги наоѓаме во соништата и во митовите. Меѓутоа, современите истражувачки тенденции во компаративната митологија целосно ги изолираат Јунговите теории како погрешни едноставно поради тоа што Јунг, при напорот на објаснување на сличностите помеѓу митовите на оддалечените култури, верува во тоа дека архетиповите постојат a priori. Проблемот е во научната поткрепа на ова „верување“ која изостанува затоа што Јунг своите тези ги темели само на еден мал дел од светското усно книжевно наследство: тој ги истражува старите европски текстови (грчките, римските, средновековните) и еден дел од азиското наследство, преку старите кинески и тибетански текстови, што значи дека надвор од неговиот истражувачки досег остануваат, на пример, келтите, нордиската митологија, големиот остаток од далечниот исток, Африка, Австралија и Јужна Америка.

\section{3 Проблематичен универзализам}

Најважната критика во овој домен на науката е насочена кон универзалистичката настроеност на одредени автори, меѓу кои се вбројува и религиологот Мирча Елијаде, еминентен претставник на чикашката антрополошка школа кој долго време останува еден од најважните проучувачи на природата на религиското искуство и, воопшто, на феноменот на сакралното. Елијаде интензивно работел на анализа на индоевропските приказни од каде што ги извлекува транскултурните митови, поврзувајќи ги со една, според него, универзална манифестација на феноменот на сакралното. Во таа смисла, теоријата (митот) за „вечното враќање“ спаѓа 
помеѓу неговите највлијателни достигнувања со оглед на тоа што неговото тврдење е во правец на осмислување на хиерофанијата како нешто што ја создава основата на религијата, раздвојувајќи го човековото искуство на доживување на просторот и времето на сакрално и профано. Воедно, локусот на влијателноста на Елијаде во науката е и локус на силната критика која доаѓа од современата наука според која Елијаде е уште еден во низата автори кои „фабрикуваат универзални митови, кои, во суштина, не постојат“. Дури, се воспоставува сличност во неговите херменевтички процедури со оние на Фројд, така што се смета дека обајцата измислуваат приказни или универзални архетипови таму каде што нив, во основа, ги нема. Археологот Жан Лоик Ле Келек тврди дека Елијаде и Фројд се слични во своите интерпретативни модуси: (...)

Елијаде ќе го измисли митот за вечното враќање. Во однос на Фројд и неговиот Едипов комплекс, тој воопшто и не проверил дали такви приказни постојат на друго место. Не значи ако ги наоѓаме митовите за мајката Земја во различни општества дека се работи за еден универзален архетип: има народи кои мислат дека Земјата е маж, и тоа многу вирилен маж, како што е тоа во стар Египет. (Le Quellec 2015: 6)

Слична интерпретативна процедура која се стреми кон проблематична универзалност, и покрај привлечноста што таа со себе ја носи, особено за оние кои митовите ги проучуваат во нивната релација со книжевните текстови, се забележува кај американскиот антрополог Џозеф Кембел. Во својата книга Херој со илjаgа лиия (The Hero with a Thousand Faces, 1949), Кембел тврди дека огромен број јуначки митови покажуваат заеднички обрасци кои се провлекуваат низ секоја поединечна приказна, односно, дека овие приказни имаат иста структура која ја рефлектира иницијациската авантура, составена од стереотипни епизоди. Неговата концепција за

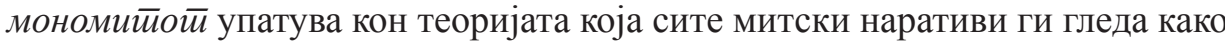
варијација на еден, единствен образец кој постои зад различните елементи и декори на приказната, независно од потеклото и времето на нејзиното создавање.

Слична теориска тенденција, која оди и во правец на систематско инвентаризирање на митовите и симболите, но со драстично намален квантум на слабости, се забележува кај Жилбер Диран, професор по културна и социјална антропологија, кој во својата фундаментална книга

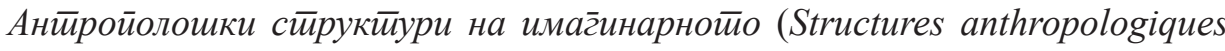
de l'imaginaire, 1960) успева да ги разјасни механизмите на симболичката имагинација и да направи изотописка класификација на слики, следејќи ја методата на конвергенција која го води до воспоставување на бипартитниот 
gневен и ноќен режим на симболизмот, во комбинација со трипартитната структура на динамичките и афективни генерализации на имагинарното.

\section{4 Инставративни наспроти редуктивни херменевтики}

Она што Диран успева да го постигне во своите истражувања кои се значајни и за компаративната митологија е востановувањето на една систематизација и, воедно, интерпретативна матрица која од една страна ги користи достигнувањата (и ги намалува слабостите) на психологијата/ рефлексологијата, а од друга страна, го ублажува формалниот апарат на структуралистичките истражувања.

Во таа смисла, од оние автори кои се занимавале со митските структури како нивна иницијална точка на интерес, значајно е да се обрне внимание на Жорж Димезил, лингвист и антрополог, специјалист за индоевропскиот културен ареал. Она што е важно да се извлече од специфичниот opus magnum на овој фасцинантен научник е сознанието за трипартитната структура. Во своето тритомно фундаментално дело Мит̄ и ейойeja (Mythe et épopée, 1968-1973) Димезил во широк распон го истражува диверзитетот на митските приказни и успева да издвои единствена трипартитна структура која ги става во паралела божествата и социјалните функции: администрацијата, војната и плодноста. Недоволно познатото дело на Димезил претставува одлична демонстрација за суштинско социолошко читање на митовите.

Конечно, уште еден неодминлив придонес во доменот на т.н. инставративни херменевтики, за компаративната митологија, но и пошироко, за темелно исчитување на текстовите на културите, претставува делото на Клод Леви-Строс. Овој еминентен антрополог-американист помеѓу 1964 и 1991 година развива сосема нова компаративна анализа на митовите на американските Индијанци, со што значајно го менува лицето на компаративната митологија. Леви-Строс се одвојува од содржините и од развојот на овие приказни и го воведува структуралното читање на елементите кои нив ги составуваат со помош на бинарните опозиции. Она што науката го добива од огромната работа на Леви-Строс е констатацијата дека митовите имаат една синтакса, една форма, како и востановувањето на правилата на трансформација од една до друга верзија на митовите. За да го постигне ова, Леви-Строс се потпира на сеопфатно етно-зоо-ботаничко знаење, а особено внимание посветил на разбирањето на механиката којашто дозволува да се помине од една верзија на митот до друга верзија. Според него оваа механика самостојно функционира, и без да знаат самите раскажувачи: така, митовите изгледаат како да се надарени со строга 
логика, тие се во суштинска врска со дескрипцијата на опипливиот свет и тоа онака како што е тој доживеан од раскажувачите и, во исто време, служат како алатки за социјална диференцијација во внатрешноста на еден културен ареал. Во суштина, како што смета современата наука, ЛевиСтрос покажува како од северот до југот на Америка може да се следат трансформациите на еден ист мит, но ако се анализира ова достигнување од историска гледна точка (што не била целта на Леви-Строс), тоа само ја засилува идејата за една голема миграција од северот кон југот, теза со која истражувачите на предисторијата, општо земено, се согласни.

\section{5 Нови тенденции}

За современите истражувања во компаративната митологија токму на овие идеи кои произлегуваат од анализите на Леви-Строс треба да им се пристапи со особено внимание. Според некои автори, одекот на анализите на ЛевиСтрос кој со децении се однесуваше само на формалната страна на митот, всушност придонесе за ограничување на перспективите на истражувањата затоа што фокусот на структуралните компарации не објаснува нешто повеќе отколку формата на митот. Студиите на големиот компаратист имаат потенцијал за објаснување на дополнително важни димензии на митот (ако се занемари дифузионистичкиот пристап како застарен) затоа што се осмелуваат да ги приближат, на пример, приказните на американските Индијанци со старите грчки, но и со јапонските приказни.

Во рамките на обновениот интерес за компаративната митологија, значајна група истражувачи се обидуваат одново во кадарот да ја стават долгата историја на човештвото. Во таа смисла, значајни се истражувањата на француските автори кои соработуваат со ревијата Анали во текот на седумдесеттите и осумдесеттите години на XX век (Жан-Пјер, Марсел Детјен, Пјер Видал-Наке, Бернар Сержан) и кои со поголем интензитет воведуваат нови начини на проучувањена историјатана антиката, потпирајќи се истовремено на историската антропологија, структуралистичкиот пристап во проучувањето на митовите и религијата, но и отворајќи се кон „индоевропската““ писта на еден Димезил, на пример. Сите овие автори, независно од нивните примарни научни интереси, ги ставаат во релација митовите и социјалните структури, религиските обичаи и политичките организации коишто одговараат на нивните респективни контексти.

Оттука, новата компаративна митологија во последната деценија се обидува одново да ги разгледа поставките на големите компаратисти од типот на Димезил и Леви-Строс и кон нивниот корпус да ги додаде придонесите на другите дисциплини, во крајна линија, за да се обиде одново 
да пристапи кон пронаоѓање на можни одговори на старите прашања. Во таа смисла археологот Ле Келек, доктор по антропологија, етнологија и предисторија, заговара пристап според кој, во светлина на погоре спомнатата центрипетална перспектива на новите истражувања, дополнително треба да се свртиме кон некои заборавени автори, како на пример, шведскиот фолклорист Карл фон Сидов, кој ја поминал половината од својот живот проучувајќи ги процесите на дифузија на митовите и народните приказни. Фон Сидов, како што посочува Ле Келек, го измислил поимот екойий, со што сакал да го концептуализира феноменот на систематични варијации кои постојат помеѓу сличните бајки/приказни/легенди - варијации, во суштина, поврзани со културните ареали. Концептот којшто Ле Келек го презема од Фон Сидов, го илустрира на следниов начин:

На пример, меѓу легендите коишто покажуваат извесна сличност на различни континенти, постојат приказни за браќа кои се во потрага по некаков предмет на потрагата, и кадетот завршува така што се покажува како полукав. Констатирано е дека во индоевропските традиции, браќата се секогаш тројца, во Африка двајца, додека во Америка доминира четворката. Ако се запомни само ова, не може да се види дека се работи за иста приказна, додека, фактички, навистина се работи за една приказна, но модификувана од културното милје кое ја присвоило. Во индоевропскиот ареал, бројот три се наоѓa - како што покажа Димезил - во институциите и во трипартитната поделба на космосот (небо/земја/подземје). Во Африка, фигурата на близнаците се наоѓa насекаде. Во Америка, четворката е присутна во поделбата на просторот на четири правци, на пример кај Индијанците Хопи, кај Инките и кај други народи. Ова е еден екойии - една систематична културна варијација која во случајов се аплицира на една иста наративна шема и ја модифицира. Ако се ставиме во перспектива на дифузија, тогаш можеме да претпоставиме дека приказната го следела истиот пат како и модерниот човек, излезен од Африка пред барем 100000 години и дека таа се проширила и трансформирала во Евроазија, а потоа одново во Америка. (Le Quellec 2015: 8)

Освен реафирмирањето на некои постари и недоволно познати концепти во новиот научен контекст, во полето на интерес на компаративната митологија нужно влегуваат и други дисциплини кои обезбедуваат нови корисни сознанија и нови аналитички пристапи. Во значајните истражувачки центри (на пример, CNRS, Националниот центар за научно истражување во Париз) сериозно се интегрираат истражувањата во генетиката, предисториската археологија и историската лингвистика, чиј огромен напредок едноставно не може да се занемари и чии сознанија сериозно придонесуваат за новите знаења за човекот и за неговата историја на Земјата. Според Ле Келек, во врска со потребата од нова перспектива 
на истражувањата на митологијата, нужно треба, на пример, да се смета на генетичарите кои произведуваат неверојатен квантитет информации со оглед на тоа што поседуваат алатки за споредување на илјадници податоци потпирајќи се на нумеричко кодирање. Во проучувањето на митовите, поделбата на митот на елементарен дел, митема, (на пример, ,јунакот е во потрага по магичен предмет“ или ,змејот јаде млада девојка“) овозможува и нејзино математичко кодирање, така што, нејзиното присуство во една приказна се означува со (1), а ако митемата ја нема, се означува со (0). Оттука, постои можност секоја приказна да се доведе до линија на код, што пак, значи, дека при споредувањето на повеќе претпоставено блиски или слични приказни би можел математички да се определи степенот на сродност и дури, да се направи обид за создавање на цели генеалошки стебла. Меѓутоа, можностите не завршуваат на таа точка, затоа што, како што вели овој еминентен научник, стеблото сѐ уште има арбитрарен дел на ова ниво. Понатаму, во истата процедура, стеблото би можело да добие форма на дрво со гранки кои би се оддалечувале, но и форма на грмушка која се развива во сите правци:

И митовите не се конституирани од гени: нивните елементи се шират и се менуваат исто толку добро преку позајмување колку и преку наследство. Значи, би требало да може да се пресмета степенот на наследство и степенот на позајмување којшто влегува во нивната сличност. Денес постојат компјутерски програми на филогенетиката кои го прават овој тип работа, кои можат да направат дистинкција на делот од наследството помеѓу два вида од делот на конвергенција која се должи на други фактори. Ваквите програми можат да се употребат и за митовите, на начин што би овозможил да се добие, многу прецизно, генеалогија на различни варијанти на наративната шема за која се сомневаме или претпоставуваме дека е иста. Овие методи се применуваат и на други културни предмети освен на митовите: јас сум се служел со нив за да ги анализирам терантропите (химери човек-животно) од пештерската традиција во Сахара разделувајќи ги нивните фигури на елементи (тело, очи, уши, муцка итн.). Преку истите пресметки, успеав да утврдам дека на почетокот, различни животински видови биле земени како модели во различни региони. (ibid, 8)

И покрај отпорот што, кај некои, го предизвикува брзиот развој на истражувачки инструменти деривирани од компјутерските технологии, дигиталната хуманистика обезбедува, очигледно, алатки кои помагаат во повторно согледување на старите енигми во општествените науки. Ле Келек ова го препознава како прозорец на можности: тука се отвора простор одново да се постават големите прашања за кои постои впечатокот дека сме се откажале да бараме одговор. Прашањата за тоа од каде доаѓаат митовите, 
дали имаат еден ист извор, каде и кога тие еволуирале, како да добиваат нова свежина.

Во ваквиот контекст, современите истражувачки трендови покажуваат дека за споредувањето на митовите и за барањето одговори во врска со претпоставките за нивното заедничко минато, еден од корисните пристапи може да биде ареолог̄uјайа. Во суштина, се работи за тоа, многубројните податоци (и методи на анализа) од различните научни дисциплини да се опсервираат од гледната точка на ареалот на дифузија на митовите и оттука да се извлекуваат заклучоци и можни теории за нивниот настанок и развивање. За ареологијата се врзуваат и имиња на истражувачи како Мајкл Вицел, харвардски професор по санскрит, кој за време на своите долги истражувачки престои во Непал, Индија и Јапонија ги проучувал ритуалите и митовите во овие несогледливо богати култури и се впуштил во исчитување на огромното поле на митски приказни расеани низ целиот свет. Во 2012 година, Вицел ја публикува својата книга Пойеклойо

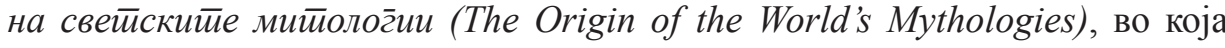
основниот теориски импулс се базира на три дијаграми, онака како што се употребуваат од страна на филолозите кои бараат начин да ги изразат релациите во јазичните семејства, во ракописните состави за кои се претпоставува дека се деривирани од еден архетип, но и од биолозите кои се обидуваат видовите да ги организираат во сродства. Во постапката на Вицел, еквиваленциите не се поставуваат помеѓу поединечните јазици, ракописи или видови од една страна и митовите, од друга страна, туку во однос на митологиите-односно корпусите митови раскажани во определени општества. Така, сведочените митологии, Вицел ги распоредува во две класи: лауразиската митологија ги опфаќа териториите на Северна Африка, Евроазија и двете Америки, додека Гондвана-митологијата се појавува на територијата на потсахарска Африка, Андаманските Острови, Папуа и Австралија, со мали „џебни остатоци“ во поединечни локализирани култури во Јужна Индија и Малаја. Дистрибуцијата на овие две класи се објаснува со помош на „Out-of-africa теоријата“ за ширењето на хомо сапиенс: почетниот егзодус од Африка (околу 65000 г. пр. н. е.) ги води митологиите од типот Гондвана источно, кон бреговите на Индискиот Океан (оставајќи малку остатоци за археолозите заради подигањето на морското ниво). Раѓањето на лауразиската митологија Вицел им го припишува на шаманите од палеолитот и се обидува провизорно да го лоцира околу 40000 г. пр. н. е. оставајќи место за претпоставката дека огромен временски сегмент бил потребен за нејзиното ширење кон Беринговиот проток и двете Америки околу 20000 г. п.н.е. Вицел укажува на тоа дека ист тип митологија може да се најде во општества со многу различни технологии, од Месопотамија, на пример, па сѐ до цивилизацијата на Маите. Двата типа митологии, 
според Вицел, потекнуваат од еден заеднички извор којшто тој го означува како „Pan-Gaian“. Амбициозниот потфат на Вицел наидува на жестоки критички реакции, но факт е дека и тој самиот го презентира својот проект како хевристички и привремен, укажувајќи имплицитно на можноста тој да биде стимул за дополнителни истражувања и промени. Во секој случај, новините и научната храброст на Вицел, помеѓу останатото, се гледаат во тоа што во голем дел од неговата обемна книга им се дава значајно место на други дисциплини кои се корисни за поткрепа на неговите тези за митот: генетиката се користи како наука која фрла светло кон објаснувањето на раните миграции; компаративната лингвистика (long-range comparative linguistics) ги осветлува јазичните феномени кои се надвор од опфатот на традиционално востановените јазични семејства; археологијата помага да се датираат појавувањата на артефакти или видови кои се спомнати во митовите. ${ }^{2}$ Во реакциите на обемната студија на Вицел постојат становишта дека оваа првична двојна поделба е убедливо аргументирана (Allen 2014). Сепак, пристапот кон светската митологија кој се потпира на тезата за заедничкото потекло, во некоја линија, претставува примена (во поширок опфат) на теориската станца на Жорж Димезил во однос на индоевропската митологија.

Во доменот на ареологијата има значаен придонес и Јуриј Березкин, професор по културна антропологија на универзитетот во Санкт Петербург, кој се обидува да ја расветли заднината на групите митови организирани на инваријантен начин и кој изработува аналитички каталози на светската митологија и фолклорот користејќи ја тематската класификација и ареалната дистрибуција на мотивите - потфат кој на извесен начин беше започнат од руските фолклористи (на пример, Владимир Проп) во дваесеттите години на минатиот век.

Во секој случај, современиот развој на истражувачките методологии од различни дисциплини покажува дека се создава нова рамка за теориските систематизации кои овозможуваат нови пристапи кон проучувањето на митовите. Ваквата состојба налага одново да се отворат старите прашања: митовите не можат да се посматраат како едноставни продукти на човековата слободна имагинација, така што и социјалната антропологија и другите науки треба да овозможат од нов агол да се погледне митот во комплексните рамки на светската историја или, барем, старите теории да се подложат на нова проверка.

2 На пример, видови кучиња за кои е докажано дека постоеле околу 15000 години пр.н.е., што, од своја страна, отвора нови дилеми особено за теориите на симболичката имагинација. 


\section{Библиографија}

Allen, N. J. (2014). Comparing mythologies on a global scale. Retrieved from: https://www.anthro.ox.ac.uk/sites/default/files/anthro/...jaso6_1_2014_99_103.pdf

Campbell, J. (1972). The hero with a thousand faces. New Jersey: Princeton University Press.

Campbell, J. (1976). The masks of God: Creative mythology. New York: Penguin Books Ltd.

Durand, G. (1989). Structures anthropologiques de l'imaginaire. Paris: Dunod.

Dumezil, G. (1995). Mythe et Épopée I-III. Paris: Gallimard.

Eliade, M. (2001). Le mythe de l'éternel retour. Paris: Folio essais.

Frazer, J. G. (1922). The golden bough. London: Macmillan.

Levi-Bruhl, L. (1922). La mentalité primitive. (cited in Primitivni mentalitet, Zagreb: Kultura, 1954)

Le Quellec, J. L. (2015). Existe-t-il des mythes universels? Sciences Humaines, 37: 6-7. Levi-Strauss, C. (1964). Mythologiques. Paris: Plon.

Tylor, E. B. (1871). Primitive Culture I-II. London: Murray.

Vico, G. (1982). Načela nove znanosti. Zagreb: Naprijed.

Schelling, F. W. J. (1988). Filosofija mitologije. Beograd: Opus.

Witzel, M. (2012). The origins of the world's mythologies. Oxford and New York: Oxford University Press. 